\title{
Produção de matéria seca e valor nutritivo do feno do tifton 85 adubado com nitrogênio e colhido com 35 dias*
}

\author{
Dry matter production and nutritive value of Tifton 85 hay fertilized with nitrogen and \\ harvested at 35 days
}

\author{
TAFFAREL, Loreno Egidio ${ }^{1}$; MESQUITA, Eduardo Eustáquio ${ }^{1}$; CASTAGNARA, \\ Deise Dalazen ${ }^{2}$; OLIVEIRA, Paulo Sérgio Rabello de ${ }^{1}$; OLIVEIRA, Newton Tavares \\ Escocard de ${ }^{1}$; GALBEIRO, Sandra ${ }^{3}$; COSTA, Patrícia Barcellos ${ }^{1}$
}

\footnotetext{
${ }^{1}$ Centro de Ciências Agrárias - Universidade Estadual do Oeste do Paraná -Marechal Cândido Rondon PR, Brasil

${ }^{2}$ Curso de Medicina Veterinária - Universidade Federal do Pampa - Uruguaiana - RS, Brasil.

${ }^{3}$ Departamento de Medicina Veterinária-Universidade Estadual do Centro-Oeste-Guarapuava-PR, Brasil.

*Email para correspondência: loreno.taffarel@gmail.com
}

RESUMO

Objetivou-se avaliar as etapas de produção de feno de capim Tifton 85 adubado com cinco doses de nitrogênio após cada corte sob a forma de ureia em cobertura. A desidratação da primeira colheita ocorreu durante seis dias em galpão, em função das condições climáticas, e a desidratação da segunda colheita ocorreu a campo durante dois dias. O delineamento experimental foi em blocos ao acaso com parcelas subdivididas no tempo, sendo as parcelas $(5 \mathrm{~m} \times 3 \mathrm{~m})$ as doses de nitrogênio $\left(0 ; 25 ; 50 ; 75\right.$ e $100 \mathrm{~kg} \mathrm{ha}^{-1}$ colheita $\left.^{-1}\right)$ e as subparcelas as etapas de produção de feno (corte, enfardamento e armazenamento). $\mathrm{O}$ nitrogênio aumentou a altura e produção de matéria seca por hectare, os teores de proteína bruta $(\mathrm{PB})$ e de proteína insolúvel em detergente ácido (PIDA) e neutro (PIDN). A secagem em galpão durante seis dias foi insuficiente para que a forragem atingisse $850 \mathrm{~g} \mathrm{~kg}^{-1}$ de MS no momento de enfardar. Entre a etapa de corte e 30 dias de armazenamento, o feno desidratado em galpão aumentou os teores de fibra em detergente neutro, de fibra em detergente de ácido, a PIDA, PIDN e a lignina e ocorreu um decréscimo de 18,9\% nos teores de PB. Ocorreu redução da digestibilidade in vitro da matéria seca (DIVMS) em 32,72\% entre a etapa de corte e 30 dias de armazenamento para o feno seco em galpão, enquanto que não houve alteração significativa na DIVMS e PB para o feno seco em dois dias a campo.

Palavras-chave: Cynodon spp., fenação, qualidade de volumosos

\section{SUMMARY}

This study aimed to evaluate the stages of production of Tifton 85 hay fertilized with five rates of nitrogen after each cutting in the form of urea in coverage. The dehydration of the first harvest took place for six days in a shed due to weather conditions and the dehydration of the second harvest occurred in the field during two days. The experimental design was a randomized block design with split plot, and the plots $(5 \mathrm{~m} \mathrm{x}$ $3 \mathrm{~m})$ were the doses of nitrogen $(0,25,50,75$ and $100 \mathrm{~kg} \mathrm{ha}^{-1} \mathrm{crop}^{-1}$ ) and the subplots steps hay production (cutting, baling, and storage). The nitrogen increased the height and dry matter production per hectare, the crude protein $(\mathrm{CP})$ and acid detergent insoluble protein (PIDA) and neutral (NDIP). The drying in a shed for six days was insufficient for the material to reach $850 \mathrm{~g} \mathrm{~kg}^{-1}$ $\mathrm{DM}$ at the time of baling. Between the stages of cut and 30 days of storage, the hay dehydrated in shed increased levels of neutral detergent fiber, detergent fiber acid, the PIDA, NDIP and lignin and decreased in $18.9 \%$ the CP levels. Ocurred a decrease in in vitro digestibility of dry matter (DM) in $32.72 \%$ between the step of cut and 30 days of storage for dry hay in the shed, while there was no significant change in IVDMD and CP for dry hay in two days in the field.

Keywords: Cynodon spp., haymaking, quality of forage 


\section{INTRODUÇÃOO}

A fenação é a conservação do valor nutritivo da forragem por meio da rápida desidratação, a qual reduz as perdas no processo de produção de feno em função da paralisação da atividade respiratória das plantas e dos microrganismos. (CALIXTO JÚNIOR et al., 2007). Várias gramíneas forrageiras bem adaptadas ao clima tropical e subtropical podem ser utilizadas para produzir feno, e entre estas se destaca o Tifton 85 (Cynodon spp), principalmente pela sua alta produtividade e valor nutricional.

Para que o capim-tifton 85 expresse seu potencial de produção de matéria seca, doses altas de adubo nitrogenado é um dos fatores importantes (CORREA et al., 2006), bem como compreender seu crescimento em diversas condições de manejo e solo (PEREIRA et al., 2012).

$\mathrm{Na}$ produção de pastagens, o ecossistema do ciclo do nitrogênio $(\mathrm{N})$ é composto por solo-planta-animal e necessita da intervenção do homem no sentido de garantir a sustentabilidade por meio da aplicação de $\mathrm{N}$ parcelado, para se evitar perdas principalmente por volatilização e por lixiviação, com o objetivo de obter maior eficiência de utilização do $\mathrm{N}$ pelas plantas forrageiras (COSTA et al., 2006).

$\mathrm{O}$ nitrogênio provoca um incremento no teor da proteína bruta (PB) (RIBEIRO \& PEREIRA, 2010) e melhora na digestibilidade in vitro da matéria seca (DIVMS), devido ao aumento da participação das folhas na matéria seca total da planta (CECATO et al., 2001). A aplicação de nitrogênio também promove acúmulo de tecidos fibrosos, como FDN e FDA que possui correlação negativa com a digestibilidade (RIBEIRO \& PEREIRA, 2010).
Por outro lado, a concentração de FDN, FDA, lignina (LIG), proteína insolúvel em detergente neutro (PIDN) e ácido (PIDA) também podem aumentar se o enfardamento e armazenamento do feno ocorrer com teores de umidade acima de $150 \mathrm{~g} \mathrm{~kg}^{-1}$ e desta forma, reduz os nutrientes digestíveis totais (NDT) e a digestibilidade (COBLENTZ \& HOFMANN, 2009; TURNER et al., 2002).

Objetivou-se com esse trabalho avaliar os efeitos de cinco doses de nitrogênio e de três etapas do processo de fenação (corte, enfardamento e 30 dias de armazenamento) com desidratação a campo e em galpão, na composição bromatológica e digestibilidade de feno de capim Tifton 85 .

\section{MATERIAL E MÉTODOS}

O experimento foi conduzido em condições de campo, na Fazenda Experimental Antônio Carlos dos Santos Pessoa, pertencente à Universidade Estadual do Oeste do Paraná, campus de Marechal Cândido Rondon, possuindo como coordenadas geográficas latitude $24^{\circ} 33^{\prime} 40^{\prime}$ ' $\mathrm{S}$, longitude $54^{\circ} 04^{\prime} 12$ ' $\mathrm{W}$ e altitude de $420 \mathrm{~m}$. O clima local, classificado segundo Koppen é do tipo Cfa subtropical com chuvas bem distribuídas durante o ano e verões quentes. As temperaturas médias do trimestre mais frio variam entre $17 \mathrm{e}$ $18^{\circ} \mathrm{C}$, do trimestre mais quente entre 28 e $29^{\circ} \mathrm{C}$ e a temperatura anual entre $22 \mathrm{e}$ $23^{\circ} \mathrm{C}$. Os totais anuais médios normais de precipitação pluvial para a região variam de 1.600 a $1.800 \mathrm{~mm}$, com trimestre mais úmido apresentando totais variando entre 400 a $500 \mathrm{~mm}$ (Iapar, 2006).

O solo da área experimental é classificado como Latossolo Vermelho 
Eutrófico (EMBRAPA, 2006) e possui as seguintes características químicas: $\mathrm{P}$ (Extrator Mehlich) - 8,15mg dm ${ }^{-3}$; MO $23,92 \mathrm{~g} \mathrm{dm}^{-3} ; \mathrm{pH} \mathrm{CaCl}_{2} 0,01 \mathrm{~mol} \mathrm{~L}^{-1}$; $\mathrm{H}+\mathrm{Al}-4,30 \mathrm{cmol}_{\mathrm{c}} \mathrm{dm}^{-3} ; \mathrm{Al}^{3+}(\mathrm{KCl} 1$ $\left.\mathrm{mol} \mathrm{L}{ }^{-1}\right)-0,05 \mathrm{cmol}_{\mathrm{c}} \mathrm{dm}^{-3} ; \mathrm{K}$ ( Extrator Mehlich) - 0,23 $\mathrm{cmol}_{\mathrm{c}} \mathrm{dm}^{-3} ; \mathrm{Ca}^{2+}(\mathrm{KCl} 1$ $\left.\mathrm{mol} \mathrm{L}{ }^{-1}\right)-3,62 \mathrm{cmol}_{\mathrm{c}} \mathrm{dm}^{-3} ; \mathrm{Mg}^{2+}(\mathrm{KCl}$ $\left.1 \mathrm{~mol} \mathrm{~L}^{-1}\right)-1,69 \mathrm{cmol}_{\mathrm{c}} \mathrm{dm}^{-3} ;$; SB $-5,54$ $\mathrm{cmol}_{\mathrm{c}} \mathrm{dm}^{-3}$; CTC - 9,84 $\mathrm{cmol}_{\mathrm{c}} \mathrm{dm}^{-3} \mathrm{~V}-$ 56,30\%; $\mathrm{Al} \mathrm{m}=0,89 \% ; \mathrm{Cu}$ (Extrator Mehlich) - 6,30; Mn (Extrator Mehlich) - 1,4; Zn (Extrator Mehlich) - 63,00, Fe (Extrator Mehlich) - 25,10 e argila $650 \mathrm{~g} \mathrm{~kg}^{-1}$.

O experimento foi instalado no campo de produção de feno implantado em 2004 com Cynodon sp. cv. Tifton-85, constituído de quatro blocos com dez unidades experimentais de $15 \mathrm{~m}^{2}(3 \mathrm{~m} \mathrm{x}$ $5 \mathrm{~m})$. O experimento teve início no dia 30 de outubro de 2010 com o corte de uniformização da forrageira e término em 11 de janeiro de 2011. As condições climáticas durante $\mathrm{o}$ período estão demonstradas na Figura 1. Os cortes foram realizados com intervalos de 35 dias de rebrota. A desidratação em cada colheita foi diferente, sendo na primeira colheita realizada durante seis dias em galpão, em razão da ocorrência de chuvas e da segunda colheita durante dois dias a campo (Tabela 1).

$\mathrm{O}$ delineamento experimental adotado para as análises bromatológicas e teores de matéria seca foi em blocos casualizados em parcelas subdivididas no tempo (BANZATTO \& KRONKA, 2006), sendo cinco doses de $\mathrm{N}(0 ; 25$;

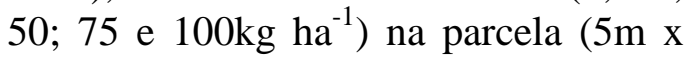
$3 \mathrm{~m})$ e três etapas de fenação (imediatamente após o corte, no enfardamento e 30 dias após o armazenamento) na subparcela, com quatro repetições. Para a produção de matéria seca por hectare e DIVMS as parcelas foram os dois cortes $\mathrm{e}$ as subparcelas as doses de $\mathrm{N}$, utilizando a forragem após o corte. Para a determinação da DIVMS foi utilizada a técnica de Tilley \& Terry (1963). O teor de matéria seca dos resíduos da digestibilidade foi analisado segundo Association of Official Analytical Chemists (AOAC, 1980).

Durante a desidratação da forragem, foi realizado o revolvimento e viragem do material diariamente, no horário entre 10:00 e 15:00 horas.

A altura do capim Tifton 85 foi mensurada no dia da colheita em quatro pontos distintos de cada subparcela com auxílio de régua graduada em milímetros. A coleta de material para determinar a produção de matéria seca total e composição química foi estimada por meio de amostragem com um quadro metálico com área conhecida $\left(0,25 \mathrm{~m}^{2}\right)$ repetidos duas vezes em cada unidade experimental, aproximadamente a $5 \mathrm{~cm}$ de altura do nível do solo. As amostras foram identificadas e embaladas em sacos de papel, pesadas e colocadas em estufa com ventilação forçada e mantidas sob temperatura de $55^{\circ} \mathrm{C}$ por 72 horas para secagem.

Após a secagem em estufa das amostras de cada etapa de fenação (corte, enfardamento e 30 dias de armazenamento), as amostras foram moídas em moinho tipo Willey, com peneira de 30 mesh, e armazenadas em sacos plásticos devidamente identificados para avaliação dos teores de matéria seca (MS), matéria mineral (MM), fibra em detergente neutro (FDN), fibra em detergente ácido (FDA), proteína insolúvel em detergente neutro (PIDN), proteína insolúvel em detergente ácido (PIDA), proteína bruta (PB), lignina (LIG), celulose (CEL) e hemicelulose (HEM) (SILVA \& QUEIROZ, 2009). 
Tabela 1. Dados climáticos no período de cortes e secagem das plantas de capim Tifton 85 (Marechal Cândido Rondon, fevereiro de 2011)

\begin{tabular}{|c|c|c|c|c|c|c|c|c|c|c|c|c|}
\hline \multirow[t]{2}{*}{ Data } & \multicolumn{3}{|c|}{ Temperatura do ar $\left({ }^{\circ} \mathrm{C}\right)$} & \multicolumn{3}{|c|}{ Umidade relativa do ar $(\%)$} & \multicolumn{3}{|c|}{ Temperatura ponto orvalho $\left({ }^{\circ} \mathrm{C}\right)$} & \multirow{2}{*}{$\begin{array}{l}\text { Veloc. } \\
\text { Vento }\end{array}$} & \multirow{2}{*}{$\begin{array}{c}\text { Radiação } \\
\left(\mathrm{KJ} / \mathrm{m}^{2}\right)\end{array}$} & \multirow{2}{*}{$\begin{array}{l}\text { Chuva } \\
\text { (mm) }\end{array}$} \\
\hline & Média & Máx. & Mín. & Média & Máx. & Mín. & Média & Máx. & Mín. & & & \\
\hline \multicolumn{13}{|c|}{$1^{\circ}$ corte 35 dias - secagem em galpão } \\
\hline 06/12/2010 & 22,9 & 28,9 & 17,3 & 85,3 & 97,0 & 65,0 & 20,2 & 23,5 & 16,6 & 3,5 & 20699,556 & 0,0 \\
\hline $07 / 12 / 2010$ & 23,7 & 27,9 & 20,7 & 88,7 & 96,0 & 75,0 & 21,7 & 24,0 & 19,0 & 4,3 & 19179,964 & 33,0 \\
\hline $08 / 12 / 2010$ & 23,1 & 27,5 & 20,0 & 92,3 & 97,0 & 76,0 & 21,7 & 24,7 & 19,1 & 1,8 & 13200,972 & 38,0 \\
\hline $09 / 12 / 2010$ & 25,1 & 31,4 & 19,3 & 80,3 & 97,0 & 47,0 & 21,1 & 23,9 & 18,1 & 1,8 & 30951,360 & 0,0 \\
\hline $10 / 12 / 2010$ & 24,0 & 30,4 & 20,5 & 85,6 & 96,0 & 67,0 & 21,4 & 25,0 & 18,8 & 4,2 & 17785,680 & 11,0 \\
\hline $11 / 12 / 2010$ & 24,6 & 29,9 & 20,2 & 82,3 & 91,0 & 68,0 & 21,3 & 24,3 & 18,3 & 3,7 & 21603,202 & 0,0 \\
\hline \multicolumn{13}{|c|}{$2^{\circ}$ corte 35 dias - secagem ao sol } \\
\hline 10/01/2011 & 26,6 & 33,9 & 20,7 & 78,9 & 96,0 & 51,0 & 22,2 & 24,7 & 20,0 & 1,8 & 25421,520 & 0,0 \\
\hline $11 / 01 / 2011$ & 24,6 & 29,2 & 21,5 & 87,6 & 96,0 & 72,0 & 22,3 & 25,3 & 20,8 & 2,1 & 16095,530 & 10,2 \\
\hline
\end{tabular}

Fonte: Estação Agrometeorológica da Universidade Estadual do Oeste do Paraná.

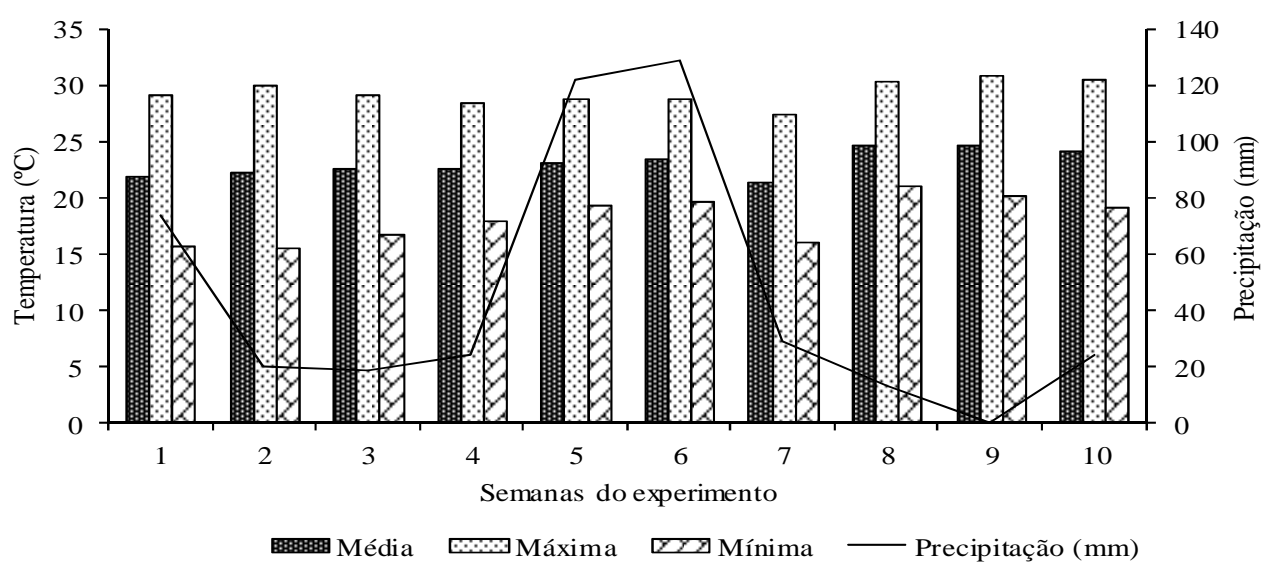

Fonte: Estação Agrometeorológica da Universidade Estadual do Oeste do Paraná.

Figura 1. Dados climáticos do período experimental (Marechal Cândido Rondon, Outubro de 2010 a Janeiro de 2011) 
Os dados foram submetidos à análise de variância e quando significativos foram testados os efeitos dos cortes para DIVMS e PMS ha ${ }^{-1}$ e das etapas de fenação (corte, enfardamento e 30 dias de armazenamento) para as análises bromatológicas por meio do teste de Tukey e doses de $\mathrm{N}$ por meio da análise de regressão. Para a escolha dos modelos foi considerado o maior grau de explicação aos dados por meio dos maiores coeficientes de determinação $\left(\mathrm{R}^{2}\right)$ e a significância ao nível de 5\%, pelo teste $\mathrm{t}$ parcial de Student para os coeficientes de regressão (PIMENTEL \& GOMES, 2009).

\section{RESULTADOS E DISCUSSÃO}

As doses de $\mathrm{N}$ promoveram aumento na PMS ha ${ }^{-1}$ e na altura da forragem e isso já era esperado. Houve diferenças entre ambos as colheitas tanto para PMS ha ${ }^{-1}$ quanto para altura. Não houve interação ( $>0,05)$ entre doses de $\mathrm{N}$ e colheitas e a PMS ha-1 média foi de 4940,86 kg MS $\mathrm{ha}^{-1}$ na primeira colheita e de $2919,71 \mathrm{~kg}$ MS ha ${ }^{-1}$ na segunda colheita. A produção de MS aumentou linearmente $\left(\hat{\mathrm{Y}}=3428,201+10,041715^{*} \mathrm{X}\right.$; $\mathrm{CV} 1=18,35 \% ; \mathrm{CV} 2=17,37 \% ; \mathrm{R}^{2}=85,94 \%$ ) com a aplicação de N. A altura média foi maior na primeira colheita $(45,8 \mathrm{~cm})$ em relação à segunda $(26,28 \mathrm{~cm})$. Não houve interação $(p>0,05)$ entre doses de $\mathrm{N}$ e cortes, entretanto, em função da diferença da produtividade e altura entre as colheitas, demonstra-se os resultados de cada colheita (Figura 2).

Atribui-se a maior $(\mathrm{p}<0,05)$ produtividade e altura na primeira colheita devido a maior precipitação em todo o ciclo $\left(243,2 \mathrm{~mm}-\right.$ da $1^{\text {a }}$ até a $5^{\text {a }}$ semana na Figura 1 em relação à segunda colheita $(148,2 \mathrm{~mm}-$ da $6^{\mathbf{a}}$ até a $10^{\mathrm{a}}$ semana na Figura 1), pois o desenvolvimento vegetativo proporcionado pelo nitrogênio promove grande absorção de água, promovendo o alongamento celular nos meristemas (QUADROS \& RODRIGUES, 2006).

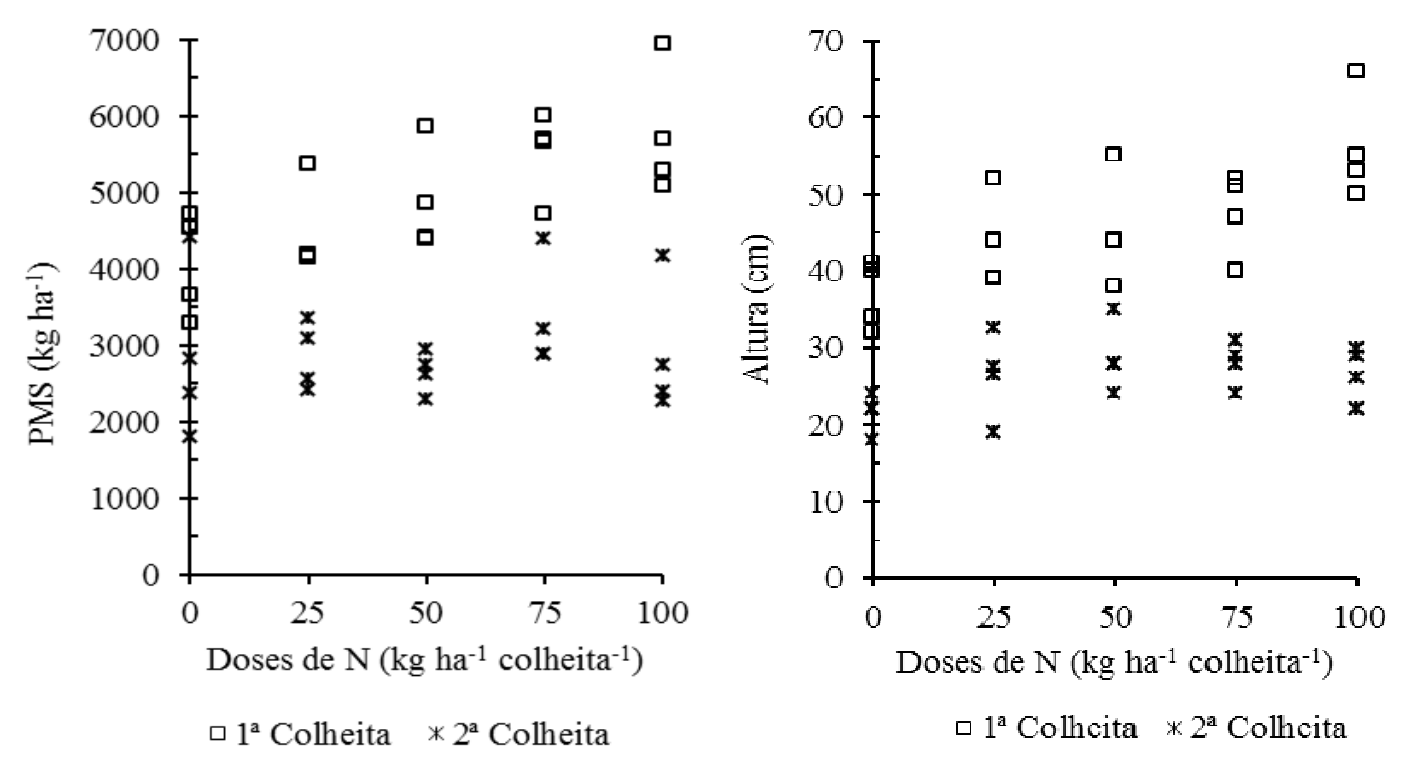

Figura 2. Produção de matéria seca por hectare e altura em centímetros da forragem de Tifton 85 em função das doses de nitrogênio e intervalo de cortes de 35 dias 
Outra explicação pode ser a maior responsividade ao $\mathrm{N}$ após os 30 dias que ocorrem em doses entre 150 e $300 \mathrm{~kg}$ de $\mathrm{N} \mathrm{ha}^{-1}$ (OLIVEIRA et al., 2010).

$\mathrm{Na}$ segunda colheita a grande precipitação $(128,6 \mathrm{~mm})$ na primeira semana do início do rebrote (na Figura 1 equivale a $6^{\text {a }}$ semana), num total do ciclo de 148,2mm, associado à alta temperatura que favorece evaporação de água do solo, pode ter contribuído para volatilização do $\mathrm{N}$ da ureia, que pode atingir até $80 \%$ (COSTA et al., 2006) e com isso ter reduzido a PMS e a altura das plantas.

A produção de matéria seca (PMS) por hectare do capim Tifton 85 sofre influência das doses de nitrogênio e frequências de corte (RIBEIRO \& PEREIRA, 2011). Esses autores encontraram incremento linear até a dose de $400 \mathrm{~kg} \mathrm{ha}^{-1}$ de $\mathrm{N}$, com eficiência de resposta de $36,8 \mathrm{~kg}$ de MS ha ${ }^{-1} \mathrm{~kg}^{-1}$ de N. Para Michelangeli et al. (2010), a maior PMS ha ${ }^{-1}$ é obtida com intervalo de cortes a cada 35 dias e com 7 a $8 \mathrm{~cm}$ de altura de corte, embora isso favoreça a infestação por ervas daninhas.

A média da eficiência de utilização do nitrogênio (EUN) foi de $8,26 \mathrm{~kg}$ de MS ha ${ }^{-1} \mathrm{~kg}^{-1}$ de $\mathrm{N}$ e é similar aos relatados por Rocha et al. (2000) e Menegatti et al. (2002) e inferior aos relatados por Ribeiro \& Pereira (2011) e Quaresma et al. (2011), de 36,8 e $22,67 \mathrm{~kg}$ MS ha $\mathrm{kg}^{-1}$ de $\mathrm{N}$, respectivamente. Isso corresponde a uma produtividade de 4,5 e 2,7 vezes mais MS por quilograma de $\mathrm{N}$, possibilitando uma maior lotação por área de animais e resultando no aumento da produção de carne ou leite por hectare ou na maior lucratividade do produtor de feno. Considerando que por vezes o custo do $\mathrm{N}$ é proibitivo (SOLLENBERGER, 2008), é importante que o $\mathrm{N}$ seja aplicado na quantidade de maior responsividade para cada condição de solo e clima para evitar as perdas por lixiviação ou volatilização, e isso se traduz na sustentabilidade $\mathrm{e}$ economicidade do sistema.

Entretanto, a média da eficiência da utilização de nitrogênio na primeira $\mathrm{e}$ segunda colheitas foram de 17,47 e $0,70 \mathrm{~kg}^{\mathrm{MS}} \mathrm{ha}^{-1} \mathrm{~kg}^{-1}$ de $\mathrm{N}$, o que evidencia a importância da aplicação de $\mathrm{N}$ em cobertura em condições ambientais adequadas e justifica a menor altura e PMS na $2^{a}$ colheita. A influência da condição climática também pode ser verificada no maior teor de MS no momento do corte (Tabela 2). A explicação é que o nitrogênio aplicado em cobertura no início do ciclo para a segunda colheita foi menos absorvido pelas plantas, provavelmente pela alta precipitação que ocorreu na sexta semana (Figura 1).

O estudo da EUN em sistemas produtivos é importante, porque indica qual a quantidade de nitrogênio aplicada que ultrapassa a capacidade da planta em absorver o nutriente para produção ou ainda acumular-se nos tecidos (CASTAGNARA et al., 2011). O nitrogênio aplicado em cobertura na forma de ureia pode facilmente ser lixiviado ou volatilizado, principalmente se houver liter ou umidade nas pastagens, pois favorece a hidrólise da ureia (OLIVEIRA et al., 2007).

Os teores de MS aumentaram após cada etapa de fenação (Tabela 2). Nas etapas de corte, os teores de MS foram de 203,7 e $262,9 \mathrm{~g} \mathrm{~kg}^{-1}$ para a $1^{\mathrm{a}}$ e $2^{\mathrm{a}}$ colheita, e esses foram teores dentro do esperado, uma vez que no momento da colheita as forragens em crescimento devem conter entre 150 e $300 \mathrm{~g} \mathrm{~kg}^{-1} \mathrm{de}$ MS (ROTZ, 1995).

$\mathrm{Na}$ etapa de enfardamento, os teores de MS aumentaram para 701,9 e 811,1g $\mathrm{kg}^{-1}$ de MS na primeira e segunda colheitas, respectivamente, ou seja, com os teores de umidade no momento de 
enfardar de 298,1 e $188,9 \mathrm{~g} \mathrm{~kg}^{-1}$ de $\mathrm{MS}$ e, portanto, ambos acima dos parâmetros de 150 a $180 \mathrm{~g} \mathrm{~kg}^{-1}$ de MS (ROTZ, 1995). A recomendação é que o feno seja enfardado com teores inferiores a $200 \mathrm{~g} \mathrm{~kg}^{-1}$ de umidade para fardos retangulares normais (com aproximadamente $12 \mathrm{~kg}$ ) ou, se os fardos são maiores, entre $160-180 \mathrm{~g} \mathrm{~kg}^{-1} \mathrm{de}$ umidade e espera-se que durante a armazenagem ocorra perda dos teores de umidade até atingir entre 80 a $150 \mathrm{~g}$ $\mathrm{kg}^{-1}$ (COLLINS \& COBLENTZ, 2007).

$\mathrm{O}$ teor de umidade na etapa de corte da $1^{\text {a }}$ colheita pode ter contribuído para esses resultados, entretanto, é atribuído maior contribuição das condições ambientais da secagem em galpão na $1^{\mathrm{a}}$ colheita e a decisão de enfardar o feno antes da chuva na $2^{\mathrm{a}}$ colheita (Tabela 1 ). A desidratação do feno na $1^{a}$ colheita foi em galpão com muros nas laterais, portanto com sombra e pouca ventilação e radiação. A umidade relativa do ar mínima do período foi de $65 \%$ em cinco dias, de um total de seis dias de desidratação. A radiação variou entre 13200 a $30951 \mathrm{KJ} / \mathrm{m}^{2}$ (Tabela 1) nos seis dias da $1^{a}$ colheita, porém, por estar em galpão, o feno não estava exposto a ela.

A radiação é o principal fator que determina a taxa de desidratação e é mais importante que a velocidade do vento e o déficit de pressão de vapor juntos nas taxas de desidratação de gramíneas, devido ao seu efeito sobre a evaporação da umidade interna das plantas (WRIGHT et al., 2000).

Após 30 dias de armazenagem, os teores de umidade do feno oriundo da $1^{\mathrm{a}}$ colheita continuam acima dos padrões (206,3 $\mathrm{g} \mathrm{kg}^{-1}$ de MS), enquanto os da $2^{\mathrm{a}}$ colheita estão em nível aceitável (171,3 $\mathrm{g} \mathrm{kg}^{-1}$ de MS). Teores de umidade acima de $150-200 \mathrm{~g} \mathrm{~kg}^{-1}$ de feno levam ao aumento da atividade microbiana, ao aquecimento a temperaturas que podem superar $50^{\circ} \mathrm{C}$ e a consequente perda de carboidratos não estruturais, o que reduz a qualidade do feno (COLLINS \& COBLENTZ, 2007).

A taxa de desidratação média do feno seco em galpão ( ${ }^{\mathrm{a}}$ colheita) foi de $0,3942 \mathrm{~g} \mathrm{~kg}^{-1}$ de $\mathrm{MS} \mathrm{h}^{-1}$. Para o feno seco a campo ( $2^{\mathrm{a}}$ colheita) foi superior a $6,10 \mathrm{~g} \mathrm{~kg}^{-1}$ de $\mathrm{MS} \mathrm{h}^{-1}$ nas primeiras 8 horas e a média de $32 \mathrm{~h}$ se aproximou de $2 \mathrm{~g} \mathrm{~kg}^{-1}$ de $\mathrm{MS} \mathrm{h}^{-1}$ e foram superiores às relatadas por Collins \& Coblentz (2007) e Calixto Júnior et al. (2007).

$\mathrm{Na}$ interação etapa de fenação e doses de $\mathrm{N}$, os teores médios de MS no momento do corte sofreram redução $(\mathrm{P}=0,1088)$ com o aumento das doses de $\mathrm{N}$ na $1^{\mathrm{a}}$ colheita, sendo respectivamente de 227,$5 ; 203,8 ; 201,8 ; 195,8$ e $189,4 \mathrm{~g}$ $\mathrm{kg}^{-1}$ de matéria natural, respectivamente para $0 ; 25 ; 50 ; 75$ e $100 \mathrm{~kg} \mathrm{ha}^{-1}$ de N. Esses dados são similares aos relatados por Correa et al. (2006). Na $2^{\mathrm{a}}$ colheita o efeito não ocorreu, possivelmente pela menor precipitação e consequente menor efeito da adubação nitrogenada.

$\mathrm{Na} 1^{\mathrm{a}}$ colheita ocorreu o aumento dos teores de minerais na fase de armazenamento (Tabela 2) e que pode ser atribuída a maior perda de nutrientes solúveis da planta como carboidratos e proteína, em função do maior tempo de desidratação (Tabela 1). Na $2^{\mathrm{a}}$ colheita, não houve alteração significativa dos teores de minerais nas etapas de fenação. Não houve interação entre doses de $\mathrm{N}$ e teores de minerais.

$\mathrm{O}$ aumento dos teores de FDN e FDA entre as etapas de corte para enfardamento e armazenamento na $1^{\mathrm{a}}$ colheita (Tabela 2) são atribuídos ao teor de umidade acima do recomendado quando $\mathrm{o}$ feno foi enfardado $\mathrm{e}$ armazenado e aumentou as perdas de carboidratos solúveis, efeito que não ocorreu na $2^{\mathrm{a}}$ colheita. Condições ambientais desfavoráveis à secagem do feno levam à perda de carboidratos 
Rev. Bras. Saúde Prod. Anim., Salvador, v.15, n.3, p.544-560 jul./set., 2014 http://www.rbspa.ufba.br ISSN 15199940

solúveis pela contínua respiração celular e quando armazenados com teores de umidade superiores aos recomendados (entre 150 e $180 \mathrm{~g} \mathrm{~kg}^{-1} \mathrm{MS}$ ) facilmente aquecem e têm como consequência aumento dos teores de FDN, FDA, LIG e PIDA (COLLINS \& COBLENTZ,
2007; Coblentz \& Hoffman, 2009). O aquecimento do feno leva à perda de carboidratos não fibrosos pela oxidação dos açúcares e reduz os nutrientes digestíveis totais e a digestibilidade (COBLENTZ \& HOFFMAN, 2010).

Tabela 2. Teores de matéria seca (MS), matéria mineral (MM), fibra em detergente neutro (FDN), fibra em detergente ácido (FDA), proteína bruta (PB), proteína insolúvel em detergente ácido (PIDA), proteína insolúvel em detergente neutro (PIDN), lignina (LIG), celulose (CEL), hemicelulose (HEM) e digestibilidade in vitro da matéria seca (DIVMS) de três etapas do processo de fenação do capim Tifton 85 em duas colheitas com intervalo de 35 dias de rebrota

\begin{tabular}{|c|c|c|c|c|c|}
\hline \multirow{2}{*}{ Colheita } & \multicolumn{3}{|c|}{ Etapa de Fenação } & \multirow{2}{*}{ CV1 $(\%)$} & \multirow{2}{*}{ CV2 $(\%)$} \\
\hline & Corte & Enfardamento & Armazenamento & & \\
\hline \multicolumn{6}{|c|}{ MS $\left(\mathrm{g} \mathrm{kg}^{-1}\right.$ de feno $)$} \\
\hline $1^{\mathrm{a}}$ & $203,7^{\mathrm{c}}$ & $701,9^{\mathrm{b}}$ & $793,7^{\mathrm{a}}$ & 4,94 & 5,7 \\
\hline $2^{a}$ & $262,9^{\mathrm{c}}$ & $811,1^{\mathrm{b}}$ & $828,7^{\mathrm{a}}$ & 2,84 & 2,48 \\
\hline \multicolumn{6}{|c|}{$\mathrm{MM}\left(\mathrm{g} \mathrm{kg}^{-1}\right.$ de MS $)$} \\
\hline $1^{\mathrm{a}}$ & $75,6^{b}$ & $76,51^{b}$ & $85,3^{\mathrm{a}}$ & 7,62 & 12,34 \\
\hline $2^{\mathrm{a}}$ & $72,8^{\mathrm{a}}$ & $68,9^{\mathrm{a}}$ & $60,6^{\mathrm{a}}$ & 19,41 & 14,35 \\
\hline \multicolumn{6}{|c|}{ FDN $\left(\mathrm{g} \mathrm{kg}^{-1}\right.$ de MS $)$} \\
\hline $1^{\mathrm{a}}$ & $787,3^{b}$ & $841,3^{\mathrm{a}}$ & $845,7^{\mathrm{a}}$ & 4,28 & 5,75 \\
\hline $2^{\mathrm{a}}$ & $839,8^{\mathrm{a}}$ & $808,3^{\mathrm{b}}$ & $768,8^{\mathrm{c}}$ & 3,72 & 5,72 \\
\hline \multicolumn{6}{|c|}{ FDA $\left(\mathrm{g} \mathrm{kg}^{-1}\right.$ de MS $)$} \\
\hline $1^{\mathrm{a}}$ & $435,1^{\mathrm{c}}$ & $533,9^{\mathrm{b}}$ & $627,1^{\mathrm{a}}$ & 8,54 & 12,92 \\
\hline $2^{\mathrm{a}}$ & $520,9^{\mathrm{a}}$ & $546,0^{\mathrm{a}}$ & $558,4^{\mathrm{a}}$ & 12,13 & 10,36 \\
\hline \multicolumn{6}{|c|}{ PB $\left(\mathrm{g} \mathrm{kg}^{-1}\right.$ de MS $)$} \\
\hline $1^{\mathrm{a}}$ & $158,9^{\mathrm{a}}$ & $148,2^{a}$ & $128,8^{b}$ & 11,06 & 6,79 \\
\hline $2^{\mathrm{a}}$ & $146,4^{\mathrm{a}}$ & $135,9^{\mathrm{a}}$ & $141,6^{\mathrm{a}}$ & 12,86 & 8,72 \\
\hline \multicolumn{6}{|c|}{ PIDA $\left(\mathrm{g} \mathrm{kg}^{-1}\right.$ de MS) } \\
\hline $1^{\mathrm{a}}$ & $69,8^{\mathrm{b}}$ & $75,4^{\mathrm{ab}}$ & $98,2^{\mathrm{a}}$ & 30,63 & 23,76 \\
\hline $2^{\mathrm{a}}$ & $92,0^{\mathrm{ab}}$ & $79,1^{\mathrm{b}}$ & $105,8^{\mathrm{a}}$ & 29,66 & 16,11 \\
\hline \multicolumn{6}{|c|}{ PIDN ( $\mathrm{g} \mathrm{kg}^{-1}$ de MS) } \\
\hline $1^{\mathrm{a}}$ & $79,3^{\mathrm{a}}$ & $70,1^{b}$ & $84,1^{a}$ & 9,03 & 8,80 \\
\hline $2^{\mathrm{a}}$ & $83,1^{\mathrm{ab}}$ & $78,3^{\mathrm{b}}$ & $90,9^{\mathrm{a}}$ & 12,64 & 10,65 \\
\hline \multicolumn{6}{|c|}{ LIG $\left(\mathrm{g} \mathrm{kg}^{-1}\right.$ de MS $)$} \\
\hline $1^{\mathrm{a}}$ & $143,5^{b}$ & $187,51^{\mathrm{ab}}$ & $196,86^{\mathrm{a}}$ & 30,75 & 15,01 \\
\hline $2^{\mathrm{a}}$ & $196,4^{\mathrm{a}}$ & $205,2^{\mathrm{a}}$ & $187,2^{\mathrm{a}}$ & 29,53 & 23,14 \\
\hline \multicolumn{6}{|c|}{ CEL $\left(\mathrm{g} \mathrm{kg}^{-1}\right.$ de $\left.\mathrm{MS}\right)$} \\
\hline $1^{\mathrm{a}}$ & $318,5^{\mathrm{a}}$ & $340,8^{\mathrm{a}}$ & $396,4^{\mathrm{a}}$ & 26,78 & 20,79 \\
\hline $2^{\mathrm{a}}$ & $418,2^{\mathrm{a}}$ & $422,5^{\mathrm{a}}$ & $370,7^{\mathrm{a}}$ & 33,29 & 15,48 \\
\hline \multicolumn{6}{|c|}{ HEM $\left(\mathrm{g} \mathrm{kg}^{-1}\right.$ de MS) } \\
\hline $1^{\mathrm{a}}$ & $352,3^{\mathrm{a}}$ & $307,3^{\mathrm{a}}$ & $218,7^{b}$ & 19,31 & 28,97 \\
\hline $2^{\mathrm{a}}$ & $318,8^{\mathrm{a}}$ & $262,2^{\mathrm{ab}}$ & $210,5^{\mathrm{b}}$ & 25,82 & 27,46 \\
\hline \multicolumn{6}{|c|}{ Digestibilidade in vitro da MS da forragem } \\
\hline $1^{\mathrm{a}}$ & $55,81^{\mathrm{a}}$ & $44,97^{\mathrm{b}}$ & $37,55^{\mathrm{c}}$ & 7,95 & 8,42 \\
\hline $2^{\mathrm{a}}$ & $52,66^{\mathrm{a}}$ & $48,68^{\mathrm{a}}$ & $53,14^{\mathrm{a}}$ & 7,97 & 12,32 \\
\hline
\end{tabular}


Na segunda colheita, os teores de FDN (Tabela 2) sofreram redução entre as etapas de corte, enfardamento e armazenamento, enquanto que os de FDA permaneceram estáveis (Tabela 2). Esses resultados são atribuídos ao curto período de desidratação (32 horas) que impediu a respiração celular e a perda de nutrientes não fibrosos. Os teores de FDN são importantes e com eles se podem estimar os nutrientes digestíveis totais (NDT) a partir da fórmula NDT $=105,2-0,66 *$ FDN proposta por Chandler (1990). Partindo dessa premissa, o NDT após 30 dias de armazenamento da $1^{\mathrm{a}}$ colheita (secagem de seis dias em galpão) foi de 49,38\% e da segunda colheita (secagem de dois dias a campo) foi de $54,46 \%$.

Não houve efeito $(p>0,05)$ dos níveis de nitrogênio e nem interação entre etapas de fenação e níveis de nitrogênio sobre os teores FDN e FDA. Em ambas as colheitas, sendo as médias para FDN de $827 ; 818 ; 846 ; 816$ e 816 e de $835 ; 796$; 812; 784 e $800 \mathrm{~g} \mathrm{~kg}^{-1}$ de MS respectivamente para a $1^{\mathrm{a}}$ e $2^{\mathrm{a}}$ colheitas para as doses de $\mathrm{N}$ de $0 ; 25 ; 50 ; 75$ e $100 \mathrm{~kg} \mathrm{ha}^{-1}$ por colheita. Para FDA as respectivas médias por dose de $\mathrm{N}$ foram de $513 ; 544 ; 561 ; 569$ e 519 e de 549; $522 ; 549 ; 520$ e 568 para a $1^{\text {a }}$ e $2^{\text {a }}$ colheitas.

Atribui-se ao menor teor de PB na $1^{\text {a }}$ colheita na etapa de armazenamento (Tabela 2) devido a essa perda de amônia, porém, as perdas podem ter sido antecipadas devido às altas temperaturas ambientes durante esse período (Figura 1). Na 2a colheita, não houve alterações dos teores de PB entre etapas de fenação, provavelmente porque as condições de produção do feno durante essas etapas foram mais favoráveis, principalmente com relação ao teor de MS em que o feno foi enfardado.
Os teores de proteína no feno são dependentes do tempo de estocagem desde o enfardamento do feno. Num período de armazenamento menor que 60 dias, os teores de PB tendem a aumentar, devido à oxidação dos carboidratos solúveis totais. Após esse período, é provável que ocorram perdas de 2,5g de $\mathrm{PB} \mathrm{kg}{ }^{-1} \mathrm{MS}$ por mês em função da volatilização da amônia produzida pela respiração microbiana (COLLINS \& COBLENTZ, 2007).

As doses de $\mathrm{N}$ promoveram aumento dos teores de proteína em ambos os cortes (Figura 3) e não houve interação entre etapas de produção do feno e doses de N. Mesmo no tratamento sem adubo, os teores de proteína permaneceram acima de $7 \%$, pois teores abaixo desse limite limitariam o consumo para bovinos (CORREA et al., 2006) o que indica a boa qualidade de volumoso obtido a partir do capim Tifton 85.

Uma interpretação recente de que níveis de PB não são suficientes para determinar a disponibilidade de proteína para o animal, uma vez que a porção da proteína ligada à fração FDA não está disponível. Em função disso a determinação dos níveis de nitrogênio ou de proteína insolúvel em detergente neutro (NIDN ou PIDN) ou em ácido (NIDA ou PIDA) pode ser considerada uma estimativa de danos causados pelo calor durante o processo de produção ou armazenamento do feno e também podem estar presentes naturalmente nas plantas (WUNSCH et al., 2007).

$\mathrm{Na}$ primeira colheita ocorreu aumento de $40,60 \%$ dos teores de PIDA entre a etapa de corte e armazenamento, enquanto que na segunda colheita esse aumento foi de $15,00 \%$ (Tabela 2). Esses resultados são atribuídos ao fato de que o feno da primeira colheita ter sido enfardado com teor de matéria seca 
de $701,9 \mathrm{~g} \mathrm{~kg}^{-1}$ de feno e da segunda colheita com $811,1 \mathrm{~g} \mathrm{~kg}^{-1}$ de feno.

A reação de Maillard é avaliada através da medição do nitrogênio que é insolúvel em solução detergente ácido (NIDA) que é transformado em PIDA. A PIDA aumenta durante as duas semanas de estocagem e os teores aumentam mais facilmente em fenos de gramas bermudas do que na alfafa quando passam por algum processo de aquecimento (COLLINS \& COBLENTZ, 2007). Clipes et al. (2010) afirmaram que a fração proteica não degradável no rúmen não é corretamente predita a partir da PIDA e por isso sugerem que não seja adotada como um estimador da fração proteica não degradável.

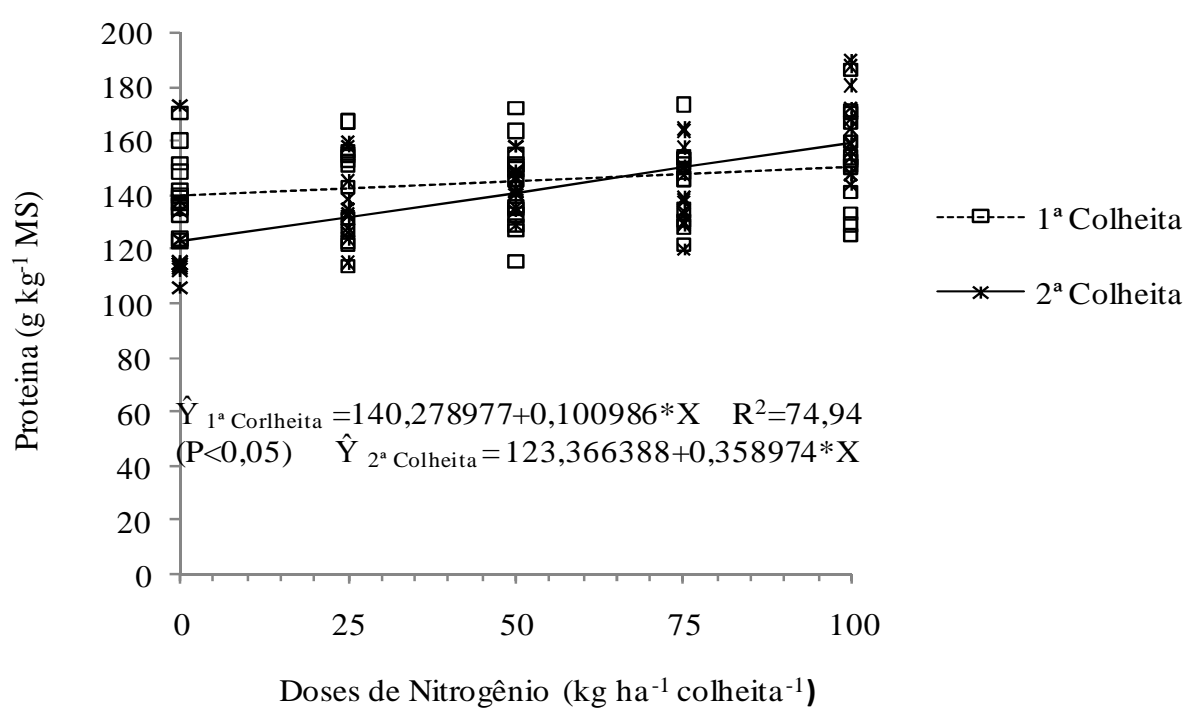

Figura 3. Teores de proteína bruta no feno de capim Tifton 85 em função das doses de nitrogênio e intervalo de cortes de 35 dias

A explicação para o aumento de $40,60 \%$ dos teores de PIDA na $1^{\text {a }}$ colheita (Tabela 2) é o fato de ter sido enfardado com teor de umidade de $298,1 \mathrm{~g} \mathrm{~kg}^{-1}$ MS, enquanto o feno da $2^{\text {a }}$ colheita foi enfardado com $188,8 \mathrm{~g} \mathrm{~kg}^{-1} \mathrm{MS}$ e o aumento foi de $15,00 \%$.

As doses de $\mathrm{N}$ não interferiam nos teores de PIDA na $1^{\mathrm{a}}$ colheita, entretanto, na $2^{\mathrm{a}}$ colheita promoveram aumentos significativos $(\mathrm{p}<0,01)$ com médias de 82,5; 90,3; 93,1; 89,4 e $106,2 \mathrm{~g} \mathrm{~kg}^{-1} \mathrm{~PB}$, para as doses de 0; 25; $50 ; 75$ e $100 \mathrm{~kg} \mathrm{ha}^{-1}$ de N, respectivamente (Figura 4).
Os teores de PIDN foram menores $(\mathrm{p}<0,05)$ na etapa de enfardamento, tanto na primeira como na segunda colheita. Os teores mais elevados de PIDN ocorreram na etapa de armazenamento, portanto, 30 dias após o enfardamento, tanto na primeira como na segunda colheita. Resultados similares também foram encontrados por Wunsch et al. (2007), que verificaram aumentos da PIDN a cada mês, durante 4 meses, após a produção do feno. 
Rev. Bras. Saúde Prod. Anim., Salvador, v.15, n.3, p.544-560 jul./set., 2014 http://www.rbspa.ufba.br ISSN 15199940

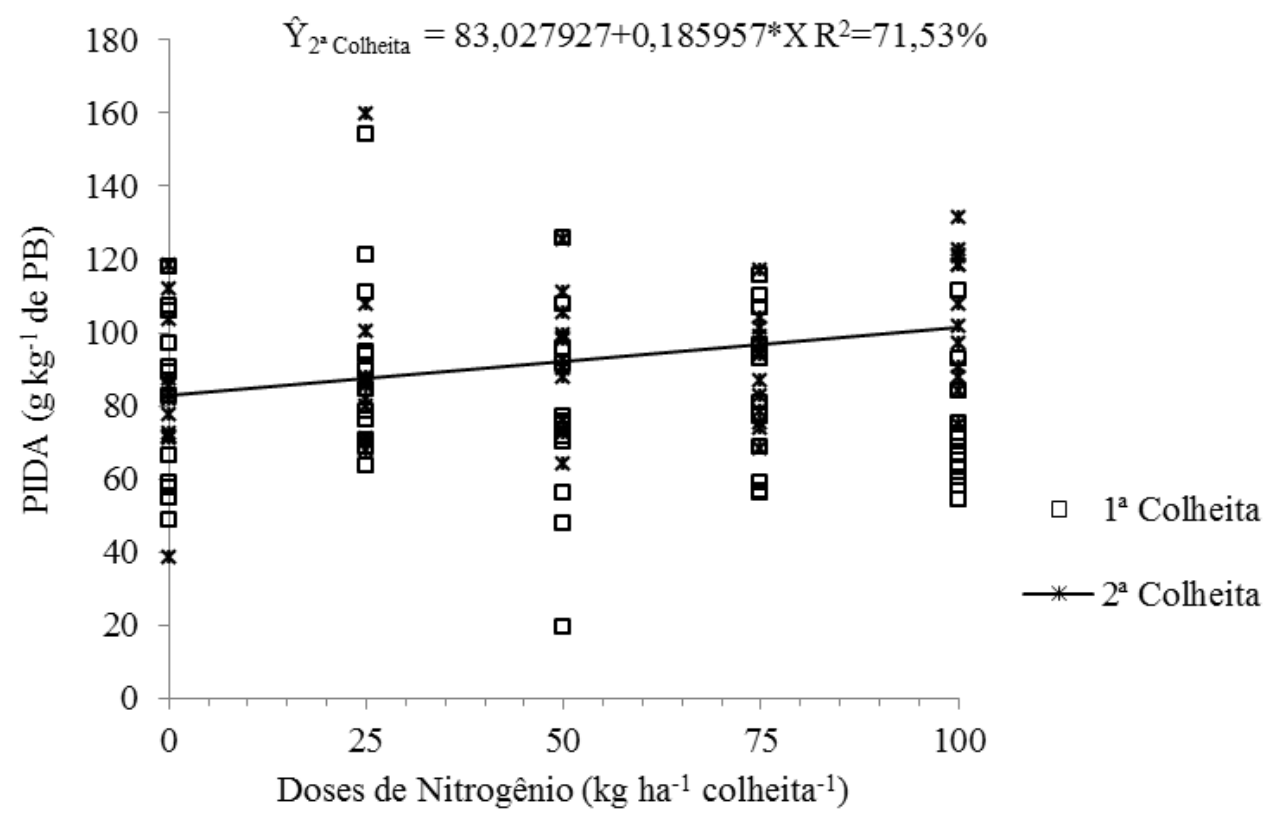

Figura 4. Teores de proteína indigestível em detergente ácido no feno de capim Tifton 85 em função das doses de nitrogênio e intervalo de cortes de 35 dias.

Uma fração do PIDN poderá ser degradável no rúmen pela flora microbiana e digestível no intestino delgado, mas uma outra fração é completamente indigestível. Os teores de PIDN, embora com teores mais elevados 30 dias após o armazenamento, não se diferenciaram dos teores no momento do corte em ambos os cortes. Os teores no momento do enfardamento foram menores que das demais etapas e não foram encontradas explicações para essa alteração. Os resultados de PIDN deste estudo são superiores aos encontrados por Gonçalves et al. (2003) para fenos de capim Tifton 85 em quatro idades de corte.

As doses de $\mathrm{N}$ não interferiram nos teores de PIDN n $1^{\text {a }}$ colheita, entretanto, na $2^{\mathrm{a}}$ colheita promoveram aumentos significativos, com médias de 73,6; 81,$7 ; 84,9 ; 84,6$ e $95,5 \mathrm{~g} \mathrm{~kg}^{-1}$ de PB para as doses de $0 ; 25 ; 50 ; 75 \mathrm{e}^{100 \mathrm{~kg} \mathrm{ha}^{-1} \mathrm{de}}$
N, respectivamente (Figura 5). São necessárias outras pesquisas para investigar se o excesso de calor provocado pela secagem ao sol aumenta, no feno de Tifton 85 , os teores de PIDA e PIDN em função de provocar reação de Maillard.

Foi significativo o aumento do teor de lignina entre a etapa de corte para enfardamento e 30 dias de armazenamento na $1^{\mathrm{a}}$ colheita (Tabela 2). $\mathrm{Na} 2^{\mathrm{a}}$ colheita as variações dos teores de lignina entre etapas de fenação não foram significativas $(\mathrm{p}>0,05)$. Os teores são considerados altos, e são superiores aos encontrados por Neres et al. (2012), entretanto, seguem a tendência dos parâmetros apresentados por Turner et al. (2002) em que fenos produzidos com maiores teores de umidade resultam no aumento dos teores de lignina em função das perdas de nutrientes solúveis. 


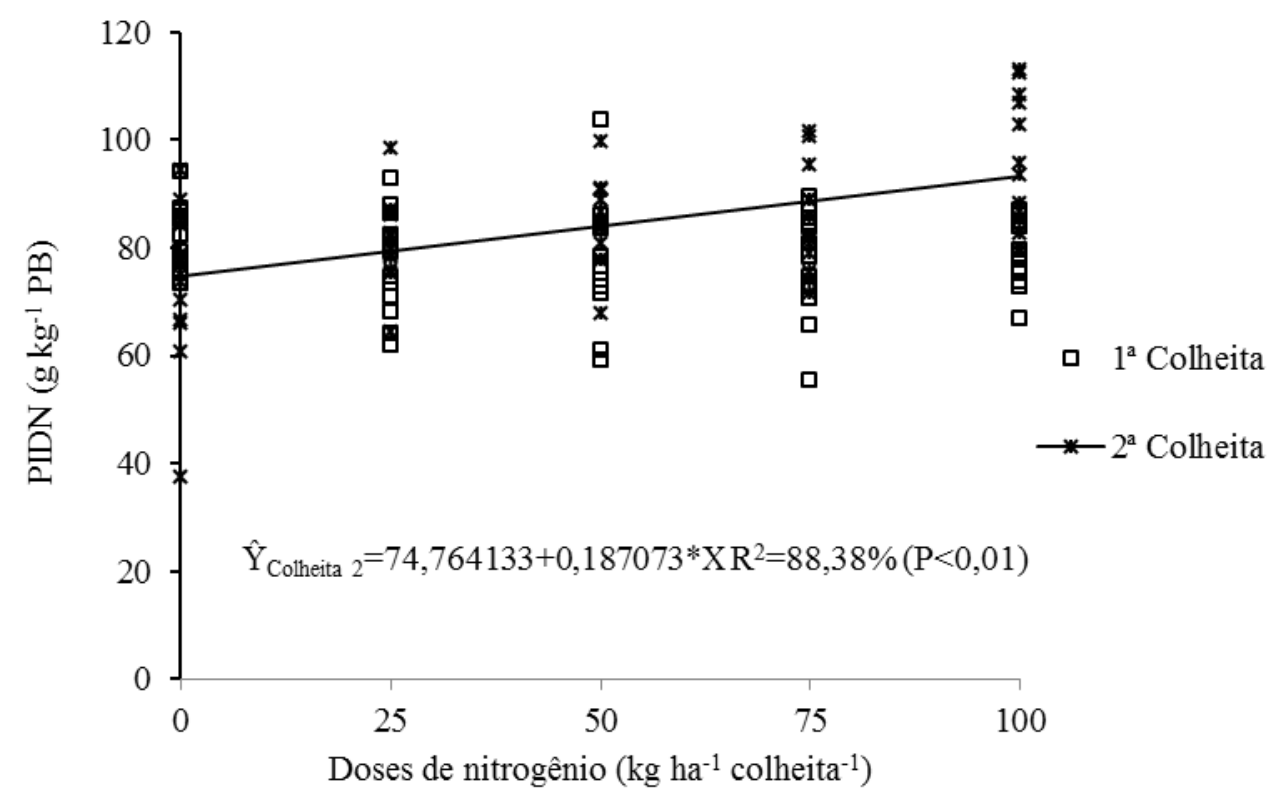

Figura 5. Teores de proteína indigestível em detergente neutro no feno de capim Tifton 85 em função das doses de nitrogênio e intervalo de cortes de 35 dias

Detmann et al. (2004) afirmaram, a respeito das equações predição de digestibilidade a partir da lignina, que pouco se conhece acerca deste potencial preditivo para gramíneas produzidas em regiões tropicais.

Van Soest (1994) afirma que o valor nutritivo de uma forragem pode ser medido pela composição química, digestibilidade in vitro e consumo, que pode revelar o potencial de produção animal em uma pastagem. A relação entre composição química com a digestibilidade e a ingestão ilustra o comportamento dos componentes do alimento. A lignina e a fibra em detergente ácido estão mais correlacionadas com a digestibilidade do que com a ingestão. Ocorre o inverso com a proteína e a fibra em detergente neutro. Esta correlação reflete os diferentes efeitos inerentes aos componentes dos alimentos sobre a variação fisiológica da digestão, ingestão e eficiência da alimentação.
O grau de biodisponibilidade da celulose e hemicelulose aos microrganismos ruminais é variável e está ligado ao grau de lignificação e as reações de Maillard (VAN SOEST, 1994), que produzem interações físicas e químicas entre os componentes carboidratos e fenólicos, o que impede de estabelecer um padrão de digestibilidade homogêneo entre alimentos e situações de alimentação (DETMANN et al., 2004).

Não houve diferença nos teores de CEL entre etapas de fenação (Tabela 2). Os teores da $1^{\text {a }}$ colheita são similares aos encontrados por Neres et al. (2012), porém, nas demais etapas (enfardamento e 30 dias após armazenagem) e na $2^{\mathrm{a}}$ colheita são superiores.

A CEL é o mais abundante carboidrato e que está presente entre 200 a $400 \mathrm{~g} \mathrm{~kg}^{-1} \mathrm{MS}$ de todas as plantas superiores. $O$ valor nutricional da celulose varia da total indigestibilidade a uma completa digestibilidade, 
dependendo principalmente do grau de lignificação. Os ruminantes digerem os conteúdos de celulose de 40 a $60 \%$ da alfafa, 48 a $90 \%$ de gramíneas temperadas, 30 a $60 \%$ de gramíneas tropicais, 40 a $60 \%$ de palhas, $94 \%$ de casca de soja, $50 \%$ da casca de algodão e de zero a $40 \%$ da madeira (Van Soest, 1994).

A maior parte da hemicelulose em ruminantes escapa da fermentação ruminal para ser fermentada no intestino (VAN SOEST, 1994). Os teores de HEM foram menores após 30 dias de armazenagem em ambos os cortes (Tabela 2). Os valores de HEM encontrados no presente estudo são similares aos encontrados por Aguiar et al. (2006) que, ao pesquisarem a composição bromatológica de milheto, capim Sudão, capim elefante e sorgo, encontraram concentrações médias de HEM que variaram entre 192,6 e $279,7 \mathrm{~g}$ $\mathrm{kg}^{-1}$ MS.

Foi significativa a variação de digestibilidade in vitro na máteria seca
(DIVMS) entre etapas de fenação na primeira colheita, sendo que ocorreu uma redução de $32,72 \%$ entre a etapa de corte ao armazenamento. $\mathrm{Na} 2^{\mathrm{a}}$ colheita não houve significância à variação da DIVMS entre as etapas de corte, enfardamento e armazenamento. Os resultados são justificados pelo aumento dos teores de fibra (FDN, FDA, PIDA, PIDN e LIG) entre etapas da fenação observado no feno obtido na $1^{\text {a }}$ colheita (Tabela 2).

As doses de nitrogênio não tiveram efeito $(p>0,05)$ na $1^{a}$ colheita, entretanto, na $2^{\mathrm{a}}$ colheita ocorreu uma curva quadrática e a máxima digestibilidade ocorreu com a dose de $67,39 \mathrm{~kg} \mathrm{ha}^{-1}$ de N (Figura 5). As médias para DIVMS para a $1^{\mathrm{a}}$ e $2^{\mathrm{a}}$ colheitas foram de 46,34; 44,67; 47,75; 44,34 e $47,43 \%$ e de 48,$57 ; 50,88 ; 51,39 ; 55,48$ e $51,12 \%$, respectivamente para as doses de $0 ; 25 ; 50 ; 75$ e $100 \mathrm{~kg} \mathrm{ha}^{-1}$ de $\mathrm{N}$ por colheita (Figura 6).

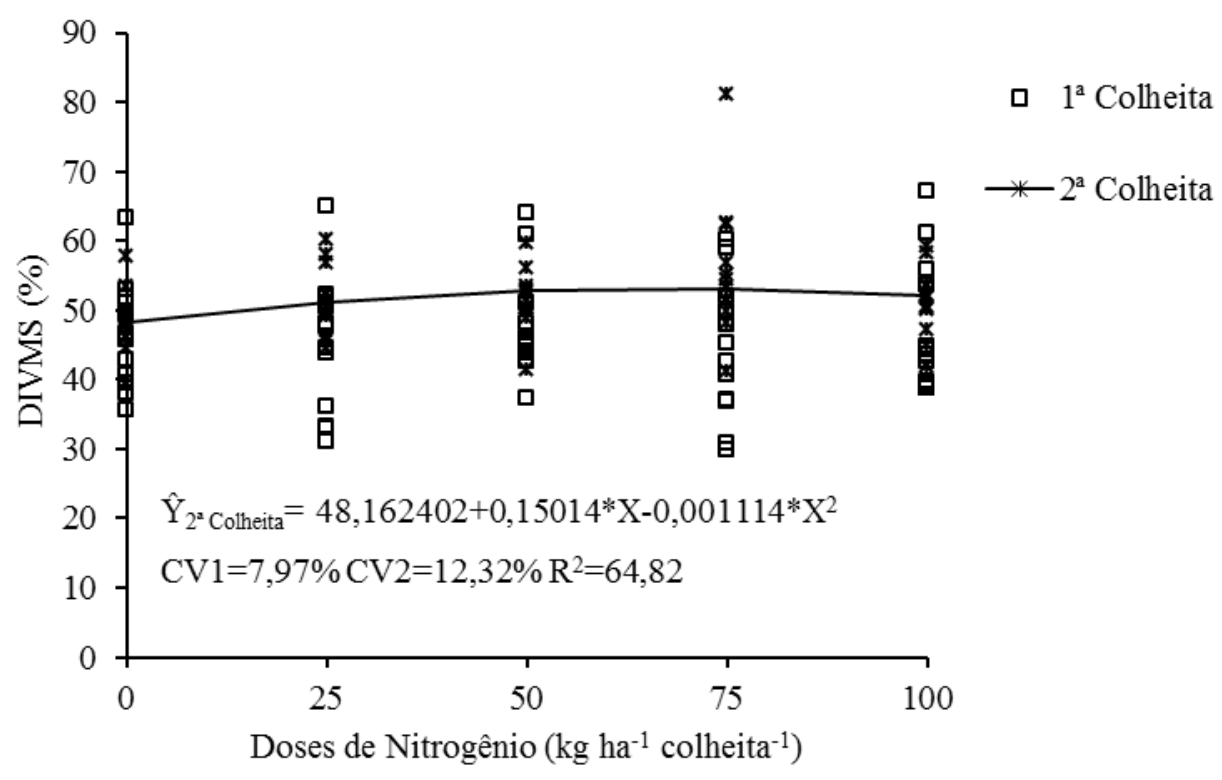

Figura 5. Digestibilidade in vitro da matéria seca na forragem de capim Tifton 85 em função das doses de nitrogênio 
Estes resultados são inferiores aos relatados por Gonçalves et al. (2003) quando avaliaram feno de tifton 85 nas idades de 28, 42, 63 e 84 dias de rebrota, com dose de $60 \mathrm{~kg} \mathrm{ha}^{-1}$ de $\mathrm{N}$. Intervalos de corte ou pastejo mais longo das forrageiras aumentam os teores de MS, porém reduzem os teores de PB e de energia disponíveis e possuem altos teores de parede celular. Essas características interferem no consumo e na digestibilidade das diferentes frações das forrageiras (VAN SOEST, 1994).

Em relação a coast-cross (Cynodon dactylon (L.) Pers X Cynodon nlemfüensisVan-deryst), a Tifton 85 (Cynodon sp.) possui maior digestibilidade dos teores de fibra e potencialmente maior digestão e digestibilidade da MS (BURN \& FISCHER, 2007). Mesmo em situações em que os teores de FDN ou de lignina são maiores que a da Coast-cross, como ocorre quando o pastejo ou colheita do feno é realizado com intervalo de 42 a 49 dias ou em anos de seca, a digestibilidade in vitro ou in situ da Tifton 85 é superior à Coast-cross (HILL et al., 2001). A explicação está nas menores concentrações de lignina insolúvel e de ligações éter do ácido ferúlico na Tifton 85 comparado a Coast-cross e a maiores concentrações no Tifton 85 do éster do ácido ferúlico. Por essa razão, a ingestão pelos animais e a digestibilidade da matéria seca do Tifton 85 é maior (HILL et al., 2001).

Corriher et al. (2007) destacou a digestibilidade de $60 \%$ da Tifton 85 e de $52,1 \%$ da Coast-cross em dois anos de pastejo, e o maior teor de proteína do leite das vacas na Tifton 85 , bem como o maior ganho de peso diário dos animais jovens.

A desidratação do feno em galpão torna inviável a desidratação do feno e aumenta os teores de fibra e reduz os teores de proteína e a digestibilidade. Quando o feno de tifton 85 é desidratado a campo em dois dias ocorre pouca variação dos teores de proteína e digestibilidade entre a etapa de corte e em 30 dias de armazenamento.

Os níveis de nitrogênio aplicados em cobertura aumentam a produtividade de matéria seca e os teores de proteína bruta da forragem verde e do feno e é dependente de fatores climáticos, principalmente quantidades de chuvas adequadas.

A desidratação do feno em galpão dificulta atingir os teores adequados de matéria seca para enfardamento e armazenagem e aumenta as perdas de nutrientes. Resulta em perdas de nutrientes que são verificadas entre a etapa de corte e trinta dias de armazenagem e observa-se aumento de até $44 \%$ nos teores de fibra em detergente ácido e perdas de até $19 \%$ de proteína e redução da digestibilidade.

$\mathrm{O}$ feno produzido em condições ambientais em até dois dias e armazenado com teores de matéria seca adequados sofre variações insignificantes na sua composição proteica, digestibilidade e fibra em detergente ácido.

\section{REFERÊNCIAS}

AGUIAR, E.M.; LIMA, G.F.C.; SANTOS, M.V.F. dos; CARVALHO, F.F.R. de; GUIM, A.; MEDEIROS, H.R. de; BORGES, A.Q. Rendimento e composição químico-bromatológica de fenos triturados de gramíneas tropicais.

Revista Brasileira de Zootecnia, v.35, n.6, p.2226-2233, 2006.

ASSOCIATION OF OFICIAL ANALYTICAL CHEMISTS - AOAC. Official methods of analysis. 15.ed. Virginia: Arlington, 1990. 1117p. 
Rev. Bras. Saúde Prod. Anim., Salvador, v.15, n.3, p.544-560 jul./set., 2014 http://www.rbspa.ufba.br ISSN 15199940

BURN. J.C.; FISHER, D.S. Dry Matter Intake and Digestibility of 'Coastal', 'Tifton 44', and 'Tifton 85'

Bermudagrass Hays Grown in the U.S. Upper South. Crop Science, v.47, n.2, p.795-810, 2007.

CALIXTO JUNIOR, M.; JOBIM, C.C.; CANTO, M.W. Taxa de desidratação e composição químico -bromatológica do feno de grama-estrela (Cynodon nlemfuemsis Vanderyst) em função de níveis de adubação nitrogenada.

Semina: Ciências Agrárias, v.28, p.493-502, 2007.

CECATO, U.; SANTOS, G.T.; MACHADO, M.A.; GOMES, L.H.; DAMACENO, J.C.; JOBIN, C.C; RIBAS, N.P.; MIRA, R.T.; CANO, C.C.P. Avaliação de cultivares do gênero Cynodon com e sem nitrogênio. Acta Scientiarum, v.23, n.4, p.781-788, 2001.

CHANDLER, C. Energy prediction of feeds by forage testing explored.

Feedstuffs, v.62, n.36, p.12, 1990.

CLIPES, R.C.; SILVA,J.F.C. da, DETMANN, E.; VÁSQUEZ,H.M.; HENRIQUES,L.T.; DONATELE, D.M.; HADDADE, I.R. Proteína insolúvel em detergente ácido como estimador da fração protéica não degradável no rúmen de forragens tropicais. Revista

Brasileira de Saúde e Produção

Animal [online], v.11, n.2, p.463-473, 2010.

COBLENTZ, W.K.; HOFFMAN, P.C. Effects of spontaneous heating on fiber composition, fiber digestibility, and in situ disappearance kinetics of neutral detergent fiber for alfafa-orchargrass hays. Journal of Dairy Science, v.92, n.6, p.2875-2895, 2009.

COBLENTZ, W.K.; HOFFMAN, P.C. Effects of spontaneous heating on estimates of total digestible nutrients for alfafa-orchardgrass hays packaged in large round bales. Journal of Dairy

Science, v.93, n.7, 2010.

COLLINS, M.; COBLENTZ, W.K. Post-harvest Physiology. In: BARNES, R.F. The Science of Grassland Agriculture. v.2, p.583-599, 2007.

CORREA, L.A.; PRIMAVESI, A.C.; PRIMAVESI, O.; FREITAS, A.R. Avaliação do efeito de fontes e doses de nitrogênio na produção e na qualidade da forragem de capimcoastcross. São Carlos, SP: Embrapa Pecuária Sudeste, 2006. (Circular Técnica, 47)

CORRIHER, V.A.; HILL, G.M.; ANDRAE, J.G.; FRETSCHEL, M.A.; MULLINIX JR., B.G. Cow and calf performance on Coastal or Tifton 85 Bermudagrass pastures with aeschynomene creep-grazing paddocks. Journal of Animal Science, v.33, p.2762-2771, 2007.

COSTA, K.A.P; OLIVEIRA, I.P.; FAQUIN, V. Adubação nitrogenada para pastagens do gênero Brachiaria em solos do cerrado. Santo Antônio de Goiás, GO: Embrapa Arroz e Feijão, 2006 (Documentos, 192)

DETMANN, E.; ZERVOUDAKIS, J.T.; CABRAL, L.S.; ROCHA JUNIOR, V.R.; VALADARES FILHO, S.de C.; QUEIROZ, A.C. de; PONCIANO, N.J.; FERNANDES, A.M. Validação de equações preditivas da fração indigestível da fibra em detergente neutro em gramíneas tropicais. Revista Brasileira de Zootecnia, v.33, n.6, p.1866-1875, 2004. Supl. 1.

GONÇALVES, G.D.; SANTOS, G.T.; JOBIM, C.C.; DAMASCENO, J.C.; CECATO, U.; BRANCO, A.F. 
Rev. Bras. Saúde Prod. Anim., Salvador, v.15, n.3, p.544-560 jul./set., 2014 http://www.rbspa.ufba.br ISSN 15199940

Determinação do consumo, digestibilidade e frações protéicas e de carboidratos do feno de Tifton $85 \mathrm{em}$ diferentes idades de corte. Revista Brasileira de Zootecnia, v.32, n.4, p.804-813, 2003.

HILL, G.M.; GATES, R.N.; WEST, J.W. Advances in bermudagrass research involving new cultivars for beef and dairy production. Journal of Animal Science, v.79, p.48-58, 2001. Edição especial.

MENEGATTI, D.P.; ROCHA, G.P.; FURTINI NETO, A.E.; MUNIZ, J.A. Nitrogênio na produção de matéria seca, teor e rendimento de proteína bruta de três gramíneas do gênero Cynodon.

Ciência e Agrotecnologia, v.26, n.3, p.633-642, 2002.

MICHELANGELI, J.A.C.; NEWMAN, Y.C.; SOLLENBERGER, L.E.; STAPLES, C.; ORTEGA, L.E.; CHRISTMAN, M.C. Managing harvest of 'Tifton 85 ' bermudagrass for production and nutritive value. Forage and Grazilands, v.8, n.1, 2010.

NERES, M.A.; CASTAGNARA, D.D.; SILVA, F.B.; OLIVEIRA, P.S.R.; MESQUITA, E.E.; BERNARDI, T.C.; GUARIANTI, A.J.; VOGT, A.S.L.

Características produtivas, estruturais e bromatológicas dos capins Tifton 85 e Piatã e do feijão-guandu cv. Super N, em cultivo singular ou em associação.

Ciência Rural, v.42, n.5, p.862-869, 2012.

OLIVEIRA, P.P.A.; TRIVELIN, P.C.O.; OLIVEIRA, W.S. Balanço do nitrogênio $\left({ }^{15} \mathrm{~N}\right)$ da ureia nos componentes de uma pastagem de capim-marandu sob recuperação em diferentes épocas de calagem. Revista Brasileira de

Zootecnia, v.36, n.6, p.1982-1989, 2007. Supl.
OLIVEIRA, A.P.P.; RISSIELLO, R.O.P.; GALZERANO, L.; COSTA JÚNIOR, J.B.G.; SILVA'R.P.; MORENZ, M.J.F. Respostas do capimTifton 85 à aplicação de nitrogênio: cobertura do solo, índice de área foliar e interceptação da radiação solar. Arquivo Brasileiro de Medicina Veterinária e Zootecnia, v.62, n.2, p.429-438, 2010.

PEREIRA, O.G.; ROVETTA, R.; RIBEIRO, K.G.; SANTOS, M.E.R.; FONSECA, D.M.; CECON, P.R. Crescimento do capim-tifton 85 sob doses de nitrogênio e alturas de corte.

Revista Brasileira de Zootecnia, v. 41, n.1, p.30-35, 2012.

QUADROS, D.G.; RODRIGUES, L.R.A. Valor nutritivo dos capins Tanzânia e Mombaça adubados com nitrogênio e sob lotação rotacionada. Acta Scientarum Animal Sciences, v.28, n.4, p.385-392, 2006.

QUARESMA, J.P.S.; ALMEIDA, R.G.; ABREU, J.G.; CABRAL, L.S.; OLIVEIRA, M.A.; CARVALHO, D.M.G. Produção e composição bromatológica do capim-tifton 85 (Cynodon spp.) submetido adoses de nitrogênio. Acta Scientarum Animal

Sciences, v.33, n.2, p.145-150, 2011.

RIBEIRO, K.G.; PEREIRA, O.G. Valor nutritivo do capim-tifton 85 sob doses de nitrogênio e idades de rebrotação.

Veterinária e Zootecnia, v.17, n.4, p.560-567, 2010.

RIBEIRO, K.G.; PEREIRA, O.G. Produtividade de matéria seca e composição mineral do capim-tifton 85 sob diferentes doses de nitrogênio e idades de rebrotação. Ciência e Agrotecnologia, v. 35, n. 4, p. 811-816, 2011. 
Rev. Bras. Saúde Prod. Anim., Salvador, v.15, n.3, p.544-560 jul./set., 2014 http://www.rbspa.ufba.br ISSN 15199940

ROCHA, G.P.; EVANGELISTA, A.R.; de LIMA, J.A. Nitrogênio na produção de matéria seca, teor e rendimento de proteína bruta de gramíneas tropicais. Pasturas Tropicales, v.22, n.1, 2000

ROTZ, A. Field curing of forages. In: MOORE, K.J.; PETERSON, M.A.

Post-harvest physiology and preservation of forages. Madison, Wisconsin, USA: Crop Science Society of America, 1995. p. 39-66.

TURNER, J.E.; COBLENTZ, W.K.; SCARBROUGH, D.A.; COFFEY, K.P.; KELLOGG, D.W.; MCBETH, L.J.;

RHEIN, R.T. Changes in nutritive value of bermudagrass hay during storage.
Agronomy Journal, v.22, n.94, p.109117, 2002.

VAN SOEST, P.J. Nutritional ecology of the ruminant. 2. ed. Ithaca: Cornell University Press, 1994. 476 p.

WRIGHT, D.A.; FROST, J.P.; KILPATRICK, D.J. The influence off weather factors on the drying rate of cut perennial riegrass herbage under controlled conditions. Grass and Forage Science, v.55, p.331-342, 2000.

Data de recebimento: 17/11/2013

Data de aprovação: 05/09/2014 